\title{
Analisis Yuridis Pemberian Upah Di Bawah UMK Bagi Tenaga Kesehatan Di Rumah Sakit
}

\author{
Aris Prio Agus Santoso ${ }^{1}$, Erna Chotidjah Suhatmi ${ }^{2}$, Indra Hastuti ${ }^{3}$, Zanuar Bayu Pamungkas ${ }^{4}$ \\ Fakultas Hukum dan Bisnis, Universitas Duta Bangsa Surakarta \\ Jl. Pinang Raya No. 47, Cemani, Grogol, Sukoharjo
}

\begin{tabular}{l}
\hline Article Info \\
\hline Article history: \\
Article Received:March 152021 \\
Publised: July 02 2021
\end{tabular}

Keywords:

Pay; Health Workers; Hospitals.

\section{Article Info}

Artikel diterima : Maret 152021

Publikasi : Juli 022021
Article history:

\footnotetext{
Keywords:

Upah; Tenaga Kesehatan; Rumah Sakit.
}

\begin{abstract}
Article 88 (1) Law no. 13/2003 concerning Manpower explains that every worker/ laborer has the right to earn an income that fulfills a decent life for humanity. In its implementation, many health workers in hospitals earn wages far below the minimum wage. The problem in this research is how the remuneration for services under the Regency / City Minimum Wage is viewed from a legal point of view, and how is the government's accountability in implementing Article 28D Paragraph (2) of the 1945 Constitution. This research method uses a normative juridical approach, by collecting data from literature studies. . The data obtained were analyzed qualitatively. Based on the research results, it is found that wages for health personnel services below the Regency / City Minimum Wage can be deferred from the minimum wage, and the difference in deferred wages is a hospital debt that must still be paid. If the hospital does not postpone the minimum wage for health workers who work in the hospital, then this is categorized as a crime. In addition, by law, the Government has carried out legal accountability to health workers as workers in the scope of hospital health, but this has not gone smoothly as planned due to the hospital's own factors.
\end{abstract}

Abstrak
Pasal 88 (1) UU No. 13/2003 tentang Ketenagakerjaan menjelaskan bahwa setiap
pekerja/buruh berhak memperoleh penghasilan yang memenuhi penghidupan yang
layak bagi kemanusiaan. Dalam implementasinya tenaga kesehatan di Rumah sakit
masih memperoleh upah jauh dibawah upah minimum. Permasalahan dalam
penelitian ini adalah bagaimana pengupahan jasa di bawah UMK ditinjau dari sudut
pandang hukum, dan pertanggungjawaban Pemerintah dalam Implementasi Pasal
28D Ayat (2) UUD 1945. Metode penelitian ini menggunakan pendekatan yuridis
normatif, dengan pengumpulan data dari studi pustaka. Data yang diperoleh dianalisis
secara kualitatif. Berdasarkan hasil penelitian ditemukan bahwa pengupahan jasa
tenaga kesehatan di bawah UMK dapat dilakukan penangguhan upah minimum, dan
selisih upah yang ditangguhkan itu merupakan hutang Rumah Sakit yang tetap wajib
dibayarkan. Apabila Rumah sakit tidak melakukan penangguhan upah minimum bagi
tenaga kesehatan, maka hal tersebut dikategorikan tindak kejahatan. Secara legislasi
Pemerintah telah melakukan pertanggungjawaban hukum kepada Tenaga Kesehatan
Rumah Sakit, namun hal ini tidak dapat berjalan mulus karena faktor Rumah Sakit
itu sendiri.
This is an open access article under the Lisensi Creative Commons Atribusi-BerbagiSerupa 4.0 Internasional

Corresponding Author:

Aris Prio Agus Santoso

Fakultas Hukum dan Bisnis, Universitas Duta

Bangsa Surakarta

Email: arisprio_santoso@udb.ac.id

1 | Analisis Yuridis Pemberian Upah Di Bawah Umk Bagi Tenaga Kesehatan Di Rumah Sakit: Aris Prio Agus Santoso 


\section{PENDAHULUAN}

\subsection{Latar Belakang}

Kesejahteraan merupakan dambaan setiap manusia dalam hidupnya. Kesejahteraan dapat dikatakan sebagai suatu kondisi ketika seluruh kebutuhan manusia terpenuhi. Terpenuhinya kebutuhan manusia dari kebutuhan yang bersifat paling dasar hingga kebutuhan untuk diakui dalam kehidupan masyarakat.

Dalam upaya memenuhi kebutuhan hidupnya, manusia tidak akan mampu menyelesaikannya atau memperolehnya tanpa bantuan orang lain, sebagaimana yang ditegaskan oleh Ibnu Khaldun dalam bukunya Muqaddimah bahwa "Manusia adalah makhluk sosial", manusia akan membutuhkan orang lain dalam rangka memenuhi kebutuhannya, seorang pedagang membutuhkan mitra dagang untuk menjual barang-barangnya dan juga membutuhkan pekerja untuk menyelesaikan atau memproduksi bahan baku menjadi barang yang bisa dikonsumsi.

Tenaga kesehatan termasuk rakyat Negara Indonesia yang juga perlu diperhatikan kesejahteraanya, karena tenaga kesehatan merupakan orang yang berprofesi untuk mengabdikan diri dalam bidang kesehatan serta memiliki pengetahuan dan/atau keterampilan melalui pendidikan di bidang kesehatan dalam menjalankan upaya kesehatan bagi masyarakat. Berprofesi sebagai tenaga kesehatan sangatlah berat karena tanggungjawab yang dipikul begitu sulit dan mengandung penuh risiko.

Jumlah tenaga kesehatan berdasarkan Pemetaan SDMK Badan PPSDM Kementerian Kesehatan RI tahun 2018, antara lain; Medis sejumlah 103.700 orang, Keperawatan sejumlah 296.876 orang, Kebidanan sejumlah 163.541 orang, Kefarmasian sejumlah 38.839 orang, Kesehatan Masyarakat sejumlah 22.949 orang, Kesehatan Lingkungan sejumlah 14.509 orang, Gizi sejumlah 18.232 orang, Keterapian Fisik sejumlah 6.044 orang, Keteknisian Medis sejumlah 23.117 orang, dan Teknik Biomedika sejumlah 32.308 orang. Kemudian Jumlah Fasyankes berdasarkan Cakupan Pemetaan SDM Kesehatan Berdasarkan Jenis Fasyankes, antara lain; Dinas Kesehatan sebanyak 548 unit, Puskesmas sebanyak 10.063 unit, Rumah Sakit sebanyak 2.846 unit, Balai Pengobatan/ Kesehatan Masyarakat sebanyak 353 unit, Gudang Farmasi sebanyak 8.226 unit, Praktik Dokter/ Praktik Dokter Gigi/ Bidan Mandiri sebanyak 7.814 unit, Optik sebanyak 454 unit, Klinik sebanyak 2.332 unit, dan Laboratorium Kesehatan sebanyak 627 unit.

Tidak semua yang bekerja pada orang lain disebut pekerja atau buruh. Seseorang disebut pekerja atau buruh adalah apabila terdapat suatu hubungan kerja yang di awali dengan perjanjian. Termasuk tenaga kesehatan, apabila mereka bekerja di sebuah instansi kesehatan maka mereka juga termasuk pekerja atau buruh. Hubungan perburuhan atau hubungan industrial disebut hubungan kerja. Hubungan kerja menurut Husni adalah:

"Hubungan antara buruh dan majikan setelah adanya perjanjian kerja yaitu suatu perjanjian di mana pihak buruh mengikatkan dirinya pada pihak majikan untuk bekerja dengan mendapatkan upah dan majikan menyatakan kesanggupanya untuk memperkerjakan si buruh dengan membayar upah".

Memperoleh penghidupan yang layak, upah kerja, jaminan kesehatan, dan jaminan kerja merupakan bagian dari kesejahteraan sosial. Tenaga Kesehatan merupakan setiap orang yang mengabdikan diri dalam bidang kesehatan serta memiliki pengetahuan dan/atau keterampilan melalui pendidikan di bidang kesehatan yang untuk jenis tertentu memerlukan kewenangan untuk melakukan upaya kesehatan di Fasilitas Pelayanan Kesehatan. Tidak hanya masyarakat umum, setiap orang termasuk profesi tenaga kesehatan berhak memperoleh kesejahteraan dalam melakukan pelayanan di Fasilitas Pelayanan Kesehatan. Akan tetapi, upah jasa yang diperoleh tidaklah sebanding dengan beban kerja yang dilakukan. Di samping itu, setiap tahunya banyak lulusan tenaga kesehatan yang saling berebut tempat kerja. Banyak pula yang membanting setir menjadi pedagang karena sulit mendapatkan pekerjaan, dan banyak pula yang menganggur karena persaingan global yang ketat di Fasilitas Pelayanan Kesehatan. 
Seperti yang diberitakan di Portal Kesmas Indonesia tahun 2017, Dinas Kesehatan (Dinkes) Sulawesi Tenggara (Sultra) mencatat jumlah pengangguran tenaga kesehatan di Sulawesi Tenggara (Sultra) saat ini mencapai 50.000 orang. Seperti yang diberitakan di Warta Bromo tahun 2017, lebih dari 20.000 Perawat yang tersebar di hampir seluruh daerah wilayah Jawa Timur menganggur atau tidak terserap sebagai tenaga profesional di bidang medis. Kemudian seperti yang diberitakan Elshinta.com tahun 2017, Data yang ada saat ini diseluruh Indonesia terdapat 863.000 perawat sedangkan yang terserap di dunia kerja seperti di Rumah Sakit, Puskesmas maupun Klinik hanya sebanyak 439.000 sedangkan sisanya menganggur.

Kebijakan upah minimum merupakan sistem pengupahan yang telah banyak diterapkan di beberapa negara, yang pada dasarnya bisa dilihat dari dua sisi. Pertama, upah minimum merupakan alat proteksi bagi pekerja untuk mempertahankan agar nilai upah yang diterima tidak menurun dalam memenuhi kebutuhan hidup sehari-hari. Kedua, sebagai alat proteksi bagi perusahaan untuk mempertahankan produktivitas pekerja. Namun kebijakan tersebut masih belum sepenuhnya diterapkan oleh pengusaha/ pemberi kerja.

Hasil pengolahan data dari Kementerian Kesehatan RI melalui program Risnakes pada tahun 2017 menunjukkan bahwa: Dari 65.646 perawat di seluruh Rumah Sakit di Indonesia, ternyata 28.4 persen gajinya masih di bawah UMP di daerahnya masing-masing. Hal ini menunjukkan bahwa 1 dari 4 perawat gajinya tidak lebih baik dari para buruh dengan gaji UMP di daerahnya. Penelusuran lebih lanjut menunjukkan bahwa dari 70.748 bidan yang bekerja di Puskesmas di Indonesia, 28.6 persen masih digaji di bawah UMP di daerahnya masing-masing. Angka ini hampir mirip dengan persentase gaji perawat yang di bawah UMP. Selain itu, ditemukan bahwa DKI Jakarta adalah tempat paling layak bagi tenaga puskesmas, mengingat hanya 0,3 persen yang digaji di bawah UMP. Sedangkan Sulawesi Barat merupakan daerah dengan 61,8 persen dari pegawai puskesmasnya digaji di bawah UMP. Hal ini menunjukkan adanya disparitas yang amat tinggi untuk tenaga kesehatan di Indonesia. Secara rata-rata nasional, tenaga puskesmas yang digaji di bawah UMP ada pada angka 34.5 persen. Kemudian dari $\mathbf{7 0 . 7 4 6}$ bidan yang disurvei, ternyata ditemukan bahwa banyak sekali provinsi yang memberikan upah minimal bidannya sebanyak Rp 50.000 saja per bulan, yakni Sumatera Utara, Sumatera Barat, Jambi, Sumatera Selatan, Sulawesi Tengah, Sulawesi Selatan, Sulawesi Tenggara, Kalimantan Selatan bahkan Jawa Timur dan Jawa Barat, sedangkan untuk 65.646 perawat yang disurvei, didapatkan bahwa gaji minimal Rp 50.000 per bulan ada di Aceh, Riau, Sumatera Selatan, Jawa Timur, Banten, Kalimantan Selatan, Sulawesi Tengah, Sulawesi Tenggara, dan Sulawesi Barat. Sayangnya, dari semua data ini, Kementerian Kesehatan hanya menyampaikan median dari gaji, bukan rata-rata/mean dari gaji tersebut. Dengan banyaknya provinsi yang memberikan gaji minimal hanya Rp 50.000 per bulan, hal ini menunjukkan bahwa bargaining position dari tenaga kesehatan di puskesmas masih sangatlah lemah, bahkan cenderung dapat dikategorikan sebagai bakti sosial/volunteer.

Dengan fakta-fakta di atas, sangat terlihat sekali bahwa profesi sebagai tenaga kesehatan itu tidak semenjanjikan yang dibicarakan oleh masyarakat. Banyaknya tenaga kesehatan yang masih digaji di bawah UMK, bahkan hanya digaji Rp 50.000 per bulan menunjukkan sangat minimnya perlindungan terhadap hak dari tenaga kesehatan. Padahal saat ini tuntutan kewajiban tenaga kesehatan sangatlah tinggi, mulai dari kompleksitas pengurusan surat tanda registrasi dan praktik, diikuti dengan biaya pendidikan berkelanjutan seperti seminar dan pelatihan yang makin mahal, ditambah lagi dengan adanya akreditasi yang mengatur standar pelayanan serinci mungkin. Kesemuanya memerlukan biaya yang sangat tinggi. Ditambah lagi makin mahalnya sekolah kesehatan karena masih dianggap sebagai profesi tentunya hal ini membuat proses pendidikan tenaga kesehatan makin tereksploitasi.

\subsection{Rumusan Masalah}

Berdasarkan latar belakang di atas yang menjadi rumusan masalah dalam penelitian ini adalah sebagai berikut: 
1. Bagaimana pengupahan jasa di bawah UMK ditinjau dari sudut pandang hukum.

2. Bagaimana pertanggungjawaban Pemerintah dalam Implementasi Pasal 28D Ayat (2) UUD 1945.

\section{KAJIAN PUSTAKA}

Upah menurut UU No. 13/2003 adalah hak pekerja/buruh yang diterima dan dinyatakan dalam bentuk uang sebagai imbalan dari pengusaha atau pemberi kerja kepada pekerja/buruh yang ditetapkan dan dibayarkan menurut suatu perjanjian kerja, kesepakatan, atau peraturan perundang undangan, termasuk tunjangan bagi pekerja/buruh dan keluarganya atas suatu pekerjaan dan/atau jasa yang telah atau akan dilakukan.

Gaji atau upah menurut UU No. 40/2004 adalah hak pekerja yang diterima dan dinyatakan dalam bentuk uang sebagai imbalan dari pemberi kerja kepada pekerja ditetapkan dan dibayar menurut suatu perjanjian kerja, kesepakatan, atau peraturan perundang-undangan, termasuk tunjangan bagi pekerja dan keluarganya atas suatu pekerjaan dan /atau jasa yang telah atau akan dilakukan.

Upah menurut PP No. 78/2015 adalah hak pekerja/buruh yang diterima dan dinyatakan dalam bentuk uang sebagai imbalan dari pengusaha atau pemberi kerja kepada pekerja/buruh yang ditetapkan dan dibayarkan menurut suatu perjanjian kerja, kesepakatan, atau peraturan perundangundangan, termasuk tunjangan bagi pekerja/buruh dan keluarganya atas suatu pekerjaan dan/atau jasa yang telah atau akan dilakukan.

Menurut Sukirno, upah yang diberikan oleh para pengusaha secara teoritis dianggap sebagai harga dari tenaga yang dikorbankan pekerja untuk kepentingan produksi, sehubungan dengan hal itu maka upah yang diterima pekerja dapat dibedakan dua macam yaitu:

1. Upah Nominal, yaitu sejumlah upah yang dinyatakan dalam bentuk uang yang diterima secara rutin oleh para pekerja;

2. Upah Riil adalah kemampuan upah nominal yang diterima oleh para pekerja jika ditukarkan dengan barang dan jasa, yang diukur berdasarkan banyaknya barang dan jasa yang bisa didapatkan dari pertukaran tersebut.

Berdasarkan uraian tersebut di atas, peneliti menyimpulkan bahwa upah adalah hak pekerja/buruh yang diterima dan dinyatakan dalam bentuk uang sebagai imbalan dari pengusaha atau pemberi kerja kepada pekerja/buruh atas suatu pekerjaan dan/atau jasa yang telah atau akan dilakukan sebagai bukti jaminan kesejahteraan bagi pekerja/buruh yang mampu mencukupi kebutuhanya sendiri dan keluarganya.

1. Sistem Pengupahan

Sistem pengupahan merupakan kerangka bagaimana upah diatur dan ditetapkan agar dapat meningkatkan kesejahteraan pekerja. Menurut Sumarsono, pengupahan di Indonesia pada umumnya didasarkan kepada tiga fungsi upah, yaitu :

a. Menjamin kehidupan yang layak bagi pekerja dan keluarganya;

b. Mencerminkan imbalan atas hasil kerja seseorang;

c. Menyediakan insentip untuk mendorong peningkatan produktivitas pekerja.

2. Kebijakan Pengupahan

Menurut Sinaga, kebijakan pengupahan tidak hanya bertujuan untuk melindungi tenaga kerja, tetapi juga untuk menjamin kelangsungan usaha dan mendorong pertumbuhan lapangan kerja produktif. Pemerintah menetapkan upah minimum sebagai jaring pengaman agar upah pekerja/buruh tidak merosot sampai tingkat yang membahayakan kesehatan dan gizi pekerja/buruh. Disisi lain pengusaha harus menyusun struktur dan skala upah sebagai dasar penetapan upah di perusahaan. Pada praktiknya, upah minimum belum dapat berfungsi sebagai jaring pengaman karena baru menjangkau sebagian kecil pekerja/buruh. Di sampaing itu upah minimum juga sering digunakan sebagai upah standar sebagai dasar penetapan upah di perusahaan. 
Menurut Pasal 3 ayat (1) UU PP No. 78/2015, Kebijakan pengupahan diarahkan untuk pencapaian penghasilan yang memenuhi penghidupan yang layak bagi Pekerja/Buruh. Kebijakan Pengupahan meliputi;

a) Upah minimum;

b) Upah kerja lembur;

c) Upah tidak masuk kerja karena berhalangan;

d) Upah tidak masuk kerja karena melakukan kegiatan lain di luar pekerjaannya;

e) Upah karena menjalankan hak waktu istirahat kerjanya;

f) bentuk dan cara pembayaran Upah;

g) denda dan potongan Upah;

h) hal-hal yang dapat diperhitungkan dengan Upah;

i) struktur dan skala pengupahan yang proporsional;

j) Upah untuk pembayaran pesangon; dan

k) Upah untuk perhitungan pajak penghasilan.

Menurut Peraturan Menteri Tenaga Kerja No. 01/MEN/1999, paling tidak ada sepuluh prinsip-prinsip yang harus ditaati dalam penetapan kebijakan upah minimum di Indonesia.

a. Upah minimum adalah upah bulanan terendah yang terdiri dari upah pokok dan tunjangan tetap.

b. Upah minimum wajib dibayar kepada bekerja secara bulanan atau dengan kesepakatan antara pekerja dan pengusaha misalnya untuk upah mingguan atau upah dua mingguan.

c. Besarnya upah pekerja yang berstatus tetap, tidak tetap, atau dalam masa percobaan adalah serendah-rendahnya sebesar upah minimum.

d. Upah minimum hanya berlaku untuk pekerja yang bekerja dibawah satu tahun.

e. Peninjauan upah dilakukan atas kesepakatan antara pekerja/serikat pekerja dan pengusaha.

f. Pekerja dengan sistem borongan atau dengan satuan hasil serendah rendahnya adalah sebesar upah minimum untuk upah bulanannya.

g. Upah pekerja harian lepas ditetapkan secara bulanan berdasar hari kehadiran (dengan pro rata basis).

h. Perusahaan yang telah memberikan upah diatas upah minimum tidak diperbolehkan menurunkan upah.

i. Dengan kenaikan upah minimum, pekerja diwajibkan untuk memelihara prestasi kerja (produktivitas) yang ukurannya dirumuskan bersama antara pekerja dan pengusaha.

j. Pengusaha yang tidak mampu menerapkan kebijakan upah minimum untuk pekerja diijinkan untuk melakukan penangguhan sementara kepada pemerintah atau pejabat yang ditunjuk.

3. Penghasilan yang Layak

Penghasilan yang layak merupakan jumlah penerimaan atau pendapatan Pekerja/Buruh dari hasil pekerjaannya sehingga mampu memenuhi kebutuhan hidup Pekerja/Buruh dan keluarganya secara wajar. Penghasilan yang layak dibagi menjadi 2 (dua) yaitu:

a. Upah

(1) Upah tanpa tunjangan;

(2)Upah pokok dan tunjangan tetap

Dalam hal komponen Upah terdiri dari Upah pokok dan tunjangan tetap, besarnya Upah pokok paling sedikit 75\% (tujuh puluh lima persen) dari jumlah Upah pokok dan tunjangan tetap.

(3)Upah pokok, tunjangan tetap, dan tunjangan tidak tetap

Dalam hal komponen Upah terdiri dari Upah pokok, tunjangan tetap, dan tunjangan tidak tetap, besarnya Upah pokok paling sedikit $75 \%$ (tujuh puluh lima persen) dari jumlah Upah pokok dan tunjangan tetap.

b. Pendapatan Non Upah

(1) Tunjangan hari raya keagamaan; 
(2) Bonus;

(3) Uang pengganti fasilitas kerja; dan/atau

(4) Uang servis pada usaha tertentu.

4. Penetapan Upah

Sesuai dengan PP No. 78/2015, upah ditetapkan Man pada struktur dan skala Upah. Struktur dan skala Upah wajib disusun oleh Pengusaha dengan memperhatikan golongan, jabatan, masa kerja, pendidikan, dan kompetensi.

a. Satuan hasil

Upah berdasarkan satuan ditetapkan sesuai dengan hasil pekerjaan yang telah disepakati. Penetapan besarnya upah dilakukan oleh Pengusaha berdasarkan hasil kesepakatan antara Pekerja/Buruh dengan Pengusaha. Penetapan Upah sebulan berdasarkan satuan hasil, untuk pemenuhan pelaksanaan ketentuan peraturan perundang-undangan ditetapkan berdasarkan Upah ratarata 3 (tiga) bulan terakhir yang diterima oleh Pekerja/Buruh.

5. Pembayaran Upah

Sesuai dengan PP No. 78/2015, pembayaran Upah oleh Pengusaha dilakukan dalam jangka waktu paling cepat seminggu 1 (satu) kali atau paling lambat sebulan 1 (satu) kali kecuali bila Perjanjian Kerja untuk waktu kurang dari satu minggu. Pembayaran upah harus dilakukan dengan mata uang rupiah Negara Republik Indonesia. Upah dapat dibayarkan secara langsung atau melalui Bank.

6. Upah Minimum

Pasal 41 ayat (1) PP No. 78/2015 menjelaskan bahwa Gubernur menetapkan Upah minimum sebagai jaring pengaman. Upah minimum merupakan upah bulanan terendah yang terdiri atas upah tanpa tunjangan dan upah pokok termasuk tunjangan tetap.

Upah minimum sebagaimana dimaksud dalam hanya berlaku bagi Pekerja/Buruh dengan masa kerja kurang dari 1 (satu) tahun pada Perusahaan yang bersangkutan. Upah bagi Pekerja/Buruh dengan masa kerja 1 (satu) tahun atau lebih dirundingkan secara bipartit antara Pekerja/Buruh dengan Pengusaha di Perusahaan yang bersangkutan.

Lebih lanjut tentang penetapan upah minimum terdapat pada Pasal 43 PP No. 78/2015:

a. Penetapan Upah minimum dilakukan setiap tahun berdasarkan kebutuhan hidup layak dan dengan memperhatikan produktivitas dan pertumbuhan ekonomi.

b. Kebutuhan hidup layak merupakan standar kebutuhan seorang Pekerja/Buruh lajang untuk dapat hidup layak secara fisik untuk kebutuhan 1 (satu) bulan.

c. Kebutuhan hidup layak terdiri atas beberapa komponen.

d. Komponen kebutuhan hidup layak terdiri atas beberapa jenis kebutuhan hidup ditinjau dalam jangka waktu 5 (lima) tahun.

e. Peninjauan komponen dan jenis kebutuhan hidup dilakukan oleh Menteri dengan mempertimbangkan hasil kajian yang dilaksanakan oleh Dewan Pengupahan Nasional.

f. Kajian yang dilaksanakan oleh Dewan Pengupahan Nasional menggunakan data dan informasi yang bersumber dari lembaga yang berwenang di bidang statistik.

g. Hasil peninjauan komponen dan jenis kebutuhan hidup menjadi dasar perhitungan upah minimum selanjutnya dengan memperhatikan produktivitas dan pertumbuhan ekonomi.

h. Ketentuan lebih lanjut mengenai kebutuhan hidup layak diatur dengan Peraturan Menteri.

Pasal 44 PP No. 78/2015, menjelaskan bahwa penetapan upah minimum dihitung dengan menggunakan formula perhitungan upah minimum, dengan rumus sebagai berikut:

$\mathrm{UM}_{\mathrm{n}}=\mathrm{UM}_{\mathrm{t}}+\left\{\mathrm{UM}_{\mathrm{t}} \mathrm{x}\left(\right.\right.$ Inflasit $\left.\left._{\mathrm{t}}+\% \Delta \mathrm{PDB}_{\mathrm{t}}\right)\right\}$

\section{METODE PENELITIAN}

Metode pendekatan yang digunakan dalam penelitian ini adalah pendekatan yuridis normatif, yaitu penelitian hukum yang dilakukan berdasarkan bahan hukum utama dengan cara menelaah teori- 
teori, konsep-konsep, asas-asas hukum serta peraturan perundang-undangan yang berhubungan dengan penelitian ini. Peneliti memilih melakukan metode ini dengan pertimbangan karena situasi yang masih terkendala Covid-19 jika penelitian tersebut dilakukan dengan pendekatan empiris. Tipe desain penelitian yang digunakan adalah Descriptive Design. Teknik pengumpulan data dalam penelitian ini dilakukan dengan cara pengumpulan data sekunder yaitu yang diperoleh melalui kepustakaan. Sumber hukum dalam penelitian ini adalah UUD 1945, UU No. 39/1999 tentang HAM, RI, UU No. 40/2004 tentang Sistem Jaminan Sosial Nasional, UU No. 11/2009 tentang Kesejahteraan Sosial, UU No. 36/2009 tentang Kesehatan, UU No. 44/2009 tentang Rumah Sakit, UU No. 36/2014 tentang Tenaga Kesehatan, PP No. 39/2012 tentang Penyelenggaraan Kesejahteraan Sosial, PP No. 78/2015 tentang Pengupahan, Permenakertrans No. 7/2013 tentang Upah Minimum. Selanjutnya data dianalisis menggunakan teknik analisis kulitatif, yaitu untuk menjawab permasalahan bagaimana pengupahan jasa di bawah UMK ditinjau dari sudut pandang hukum dan bagaimana pertanggungjawaban Pemerintah dalam Implementasi Pasal 28D Ayat (2) UUD 1945.

\section{HASIL DAN PEMBAHASAN}

\subsection{Pengupahan jasa Tenaga Kesehatan di bawah UMK ditinjau dari sudut pandang hukum}

Kesejahteraan seseorang akan terpenuhi jika kebutuhan mereka tercukupi, kesejahteraan sendiri mempunyai beberapa aspek yang menjadi indikatornya, di mana salah satunya adalah terpenuhinya kebutuhan seseorang yang bersifat materi, kesejahteraan yang oleh Al-ghazali dikenal dengan istilah (al-mashlahah) yang diharapkan oleh manusia tidak bisa dipisahkan dengan unsur harta, karena harta merupakan salah satu unsur utama dalam memenuhi kebutuhan pokok, yaitu sandang, pangan dan papan.

Kesejahteraan seorang tenaga kerja dalam bekerja dapat dilihat dari besar penghasilan yang diterima dari tempatnya bekerja, karena sejatinya menurut Pasal 4 ayat (1) Peraturan pemerintah No. 78 tahun 2015 tentang Pengupahan, penghasilan yang layak merupakan jumlah penerimaan atau pendapatan Pekerja/Buruh dari hasil pekerjaannya sehingga mampu memenuhi kebutuhan hidup Pekerja/Buruh dan keluarganya secara wajar. Hal ini dapat dimaknai bahwa apabila penghasilan yang diterima tidak dapat digunakan untuk memenuhi kebutuhan tenaga kerja dan keluarganya, maka dapat dikatakan bahwa tenaga kerja tersebut belumlah sejahtera.

Upah merupakan bagian dari penghasilan. Upah menurut UU No. 13/2003 adalah hak pekerja/buruh yang diterima dan dinyatakan dalam bentuk uang sebagai imbalan dari pengusaha atau pemberi kerja kepada pekerja/buruh yang ditetapkan dan dibayarkan menurut suatu perjanjian kerja, kesepakatan, atau peraturan perundang undangan, termasuk tunjangan bagi pekerja/buruh dan keluarganya atas suatu pekerjaan dan/atau jasa yang telah atau akan dilakukan.

Dalam implementasinya ternyata tidak semua Rumah Sakit dapat memberikan upah sesuai dengan UMK. Tenaga Kesehatan sebagai tenaga kerja dalam lingkup kesehatan seharunya juga memperoleh imbalan yang setara dengan jasa yang mereka berikan di Rumah Sakit. Pasal 28 D ayat (2) UUD 1945 menegaskan bahwa:

"Setiap orang berhak untuk bekerja serta mendapat imbalan dan perlakuan yang adil dan layak dalam hubungan kerja".

Pasal tersebut diperkuat dengan Pasal 88 (1) UU No. 13/2003 tentang Ketenagakerjaan yang menjelaskan bahwa:

"Setiap pekerja/buruh berhak memperoleh penghasilan yang memenuhi penghidupan yang layak bagi kemanusiaan".

Jika dilihat pada pasal 90 ayat (1) dan (2) menyebutkan bahwa:

(1)Pengusaha dilarang membayar upah lebih rendah dari upah minimum.

(2)Bagi pengusaha yang tidak mampu membayar upah minimum sdapat dilakukan penangguhan.

Penjelasannya Pasal 20 ayat (2), yaitu memberikan kesempatan kepada pengusaha yang tidak mampu membayar upah minimum dapat melakukan penangguhan. Dalam penjelasannya 
dikatakan bahwa penangguhan ini berbatas waktu tertentu, jika jangka waktu yang diberikan sudah habis maka pengusaha wajib melaksanakan upah minimum yang berlaku pada saat itu;

Hal tersebut telah melahirkan ketidakpastian, dimana upah minimum yang ditetapkan oleh pemerintah merupakan jaring pengaman (safety net) menjadi tidak pasti karena dimungkinkan untuk menyimpangi ketentuan tersebut sehingga upah yang diterima oleh pekerja/buruh menjadi dibawah standard Kebutuhan Hidup Layak hal ini bertentangan dengan ketentuan Pasal 28 D ayat (1) dan ayat (2) UUD 1945.

Berdasarkan Putusan Mahkamah Konstitusi Nomor 72/PUU-XIII/2015, menegaskan bahwa penangguhan pembayaran upah minimum pada dasarnya tidak serta-merta menghilangkan kewajiban pengusaha untuk membayar selisih upah minimum dengan pembayaran yang dilakukan oleh pengusaha selama masa penangguhan tersebut. Dengan kata lain selisih upah minimum dengan pembayaran yang dilakukan oleh pengusaha selama masa penangguhan adalah hutang pengusaha yang harus dibayarkan kepada pekerja/buruh. Hal tersebut demi memberikan perlindungan hukum dan kepastian hukum bagi pekerja/buruh untuk dapat menerima penghasilan yang layak bagi kemanusiaan sekaligus memberikan tanggungjawab kepada pengusaha agar yang bersangkutan tidak berlindung dibalik ketidakmampuan tersebut. Pembayaran upah dibawah upah minimum oleh pengusaha yang didasarkan atas penetapan pejabat yang berwenang/Gubernur atas permintaan dari pengusaha sangat rentan terhadap penyalahgunaan kewenangan oleh penguasa (abuse of power). Oleh karena itu upah minimum dengan pembayaran yang dilakukan oleh pengusaha tetap menjadi kewajiban pengusaha untuk membayarnya.

Pasal 185 ayat (1) menyebutkan bahwa:

(1) Pengusaha yang membayar upah lebih rendah dari upah minimum dikenakan sanksi pidana penjara paling singkat 1 (satu) tahun dan paling lama 4 (empat) tahun dan/atau denda paling sedikit Rp 100.000.000,00 (seratus juta rupiah) dan paling banyak Rp 400.000.000,00 (empat ratus juta rupiah).

(2) Tindak pidana pada pasal di atas merupakan tindak pidana kejahatan.

Kemudian pada Pasal 3 ayat (1) Kepmenakertrans No. KEP.231/MEN/2003 Tentang Tata Cara Penangguhan Pelaksanaan Upah Minimum dijelaskan bahwa

"Permohonan penangguhan pelaksanaan upah minimum diajukan oleh pengusaha kepada Gubernur melalui Instansi yang bertanggung jawab di bidang ketenagakerjaan Provinsi paling lambat 10 (sepuluh) hari sebelum tanggal berlakunya upah minimum”.

Pasal 4 (1) Kepmenakertrans No. KEP.231/MEN/2003 Tentang Tata Cara Penangguhan Pelaksanaan Upah Minimum menyebutkan bahwa:

Permohonan penangguhan pelaksanaan upah minimum harus disertai dengan:

a. Naskah asli kesepakatan tertulis antara pengusaha dengan serikat pekerja/serikat buruh atau pekerja/buruh perusahaan yang bersangkutan;

b. Laporan keuangan perusahaan yang terdiri dari neraca, perhitungan rugi/laba beserta penjelasan-penjelasan untuk 2 (dua) tahun terakhir;

c. Salinan akte pendirian perusahaan;

d. Data upah menurut jabatan pekerja/buruh;

e. Jumlah pekerja/buruh seluruhnya dan jumlah pekerja/buruh yang dimohonkan penangguhan pelaksanaan upah minimum;

f. Perkembangan produksi dan pemasaran selama 2 (dua) tahun terakhir, serta rencana produksi dan pemasaran untuk 2 (dua) tahun yang akan datang;

Ketentuan di atas dapat diartikan bahwa apabila pengusaha tidak melakukan permohonan penangguhan kepada Gubernur melalui Instansi yang bertanggung jawab di bidang ketenagakerjaan Provinsi, maka hal tersebut akan menjadi suatu tindak pidana kejahatan sebagaimana Pasal 185 ayat (1) dan (2) UU No.13/2003. 
Kemudian pada Pasal 91 ayat (1) dan (2) menyebutkan bahwa:

(1)Pengaturan pengupahan yang ditetapkan atas kesepakatan antara pengusaha dan pekerja/buruh atau serikat pekerja/serikat buruh tidak boleh lebih rendah dari ketentuan pengupahan yang ditetapkan peraturan perundang-undangan yang berlaku.

(2)Dalam hal kesepakatan lebih rendah atau bertentangan dengan peraturan perundang-undangan, kesepakatan tersebut batal demi hukum, dan pengusaha wajib membayar upah pekerja/buruh menurut peraturan perundang-undangan yang berlaku.

Hal ini dapat dimaknai bahwa perjanjian antara pekerja dan pengusaha mengenai upah harus dibuat berdasarkan perundang-undangan yang berlaku karena kalau tidak maka perjanjian sebutakan gugur demi hukum. Dalam perundang-undangan yang berlaku, maka terkait upah haruslah disamakan dengan UMK kota/kabupaten di tempat berdirinya Rumah Sakit tersebut.

Dalam hal perjanjian kerja, Pimpinan Rumah Sakit juga harus memperhatikan peraturan perundang-undangan yang berlaku, karena apabila perjanjian kerja tersebut mengandung pasalpasal yang bertentangan dengan hukum maka perjanjian kerja itu juga akan gugur demi hukum. seperti halnya upah/gaji yang diterimakan, apabila di dalam perjanjian tersebut dijumpai bahwa upah/gaji tenaga kesehatan dibawah UMK maka hal tersebut dipastikan bertentangan dengan UU No.13/2003, dan apabila dalam perjanjian tersebut juga tidak ada penjelasan mengenai penangguhan upah minimum mka perjanjian tersebut juga akan gugur demi hukum, selain itu Tenaga Kesehatan tersebut juga tidak dilaporkan kepada Gubernur melalui Instansi yang bertanggung jawab di bidang ketenagakerjaan Provinsi, maka dapat dipastikan bahwa Rumah Sakit tersebut telah melakukan perbuatan melawan hukum.

Dari seluruh uraian tersebut di atas, dapat ditarik kesimpulan bahwa pengupahan jasa tenaga kesehatan di bawah UMK dapat dilakukan penangguhan upah minimum, dan selisih upah yang ditangguhkan itu merupakan hutang Rumah Sakit yang tetap wajib dibayarkan. Apabila Rumah sakit tidak melakukan penangguhan upah minimum kepada tenaga kesehatan yang bekerja di Rumah Sakit, maka hal tersebut dikategorikan tindak kejahatan dengan sanksi pidana penjara paling singkat 1 (satu) tahun dan paling lama 4 (empat) tahun dan/atau denda paling sedikit Rp. 100.000.000,00 (seratus juta rupiah) dan paling banyak Rp. 400.000.000,00 (empat ratus juta rupiah).

\subsection{Pertanggungjawaban Pemerintah dalam Implementasi Pasal 28D Ayat (2) UUD 1945}

Dalam hukum administrasi negara, ada beberapa macam tindakan pemerintah yang merupakan pertanggungjawaban hukum dalam rangka menyelenggarakan kepentingan umum, yaitu:

a. Membebankan kewajiban-kewajban pada organ-organ itu untuk menyelenggarakan kepentingan umum;

b. Mengeluarkan undang-undang yang bersifat melarang atau menyeluruh yang ditujukan pada tiap-tiap warga negara untuk melakukan perbuatan (tingkah laku) yang perlu demi kepentingan umum;

c. Memberikan perintah atau ketetapan yang bersifat memberikan beban;

d. Memberikan subsidi atau bantuan kepada swasta;

e. Memberikan kedudukan hukum (rechtsatus) kepada seseorang sesuai dengan keingnanya sehingga orang tersebut mempunyai hak dan kewajiban;

f. Melakukan pengawasan terhadap pekerjaan swasta;

g. Bekerjasama dengan perusahaan lain dalam bentuk-bentuk yang ditentukan untuk kepentingan umum;

h. Mengadakan perjanjian dengan warga negara berdasarkan hal-hal yang diatur dalam hukum.

Penyelenggaraan kenegaraan dan pemerintahan, pertanggungjawaban itu melekat pada jabatan, yang secara yuridis dilekati dengan kewenangan. Dalam perpektif hukum publik, kewenangan inilah yang memunculkan adanya pertanggungjawaban. Pemberian wewenang 
tertentu untuk melakukan tindakan hukum tertentu menimbulkan pertanggungjawaban atas penggunaan wewenang itu. Menurut Suwoto, dalam sistem pembagian kekuasaan berlaku prinsip bahwa setiap kekuasaan wajib dipertanggungjawabkan. Oleh karena itu, dalam setiap pemberian kekuasaan harus sudah dipikirkan beban tanggungjawab bagi setiap penerima kekuasaan. Kesediaan untuk melaksanakan tanggungjawab secara inklusif sudah diterima pada waktu menerima kekuasaan. Dengan demikian, maka penyelenggaraan pemerintahan tidak boleh menimbulkan kerugian bagi warga negara.

Menurut Titmus, secara rinci ada tiga alasan utama yang perlu ditegaskan oleh negara dalam menjalankan fungsinya:

a. Negara harus menjamin tiap individu dan keluarga untuk memperoleh pendapatan minimum agar mampu memenuhi kebutuhan paling pokok.

b. Negara harus memberi perlindungan sosial jika individu dan keluarga ada dalam situasi rentan sehingga mereka menghadapi social contingencies seperti usia lanjut, menganggur miskin yang memicu pada krisis sosial.

c. Semua warga negara tanpa membedakan status dan kelas social harus dijamin untuk memperoleh akses pelayanan sosial dasar seperti pendidikan, pemenuhan gizi, sanitasi, dan air bersih.

Dalam bidang ekonomi, ada empat fungsi negara, yaitu; negara sebagai penjamin (provider) kesejahteraan rakyat, negara sebagai pengatur (regulator), negara sebagai pengusaha (entrepreneur) atau menjalankan sektor-sektor tertentu melalui BUMN, dan negara sebagai wasit (umpire). Sedangkan tugas dan tanggungjawab negara adalah mendukung dan secara langsung menyediakan berbagai pelayanan publik berlandaskan pada apa yang menjadi kebutuhan dan kepentingan publik dalam upaya mewujudkan kesejahteraan publik (bidang ekonomi, politik, sosial, budaya, keamanan, dan sebagainya). Tugas negara dan pemerintah bukan menghilangkan atau membatasi perasaan dan paresiasi masyarakatnya, tetapi mendukung dan menstimulasi masyarakat untuk ikut serta mengoptimalisasi kesejahteraanya.

Secara legislatif, sebenarnya Pemerintah telah bertanggungjawab atas pemberian upah minimum kepada tenaga kesehatan sebagaimana yang tertuang dalam Pasal 15 Permenakertrans No.7/2013 yang berbunyi:

(1)Pengusaha dilarang membayar upah lebih rendah dari upah minimum yang telah ditetapkan.

(2)Upah minimum hanya berlaku bagi pekerja/buruh yang mempunya masa kerja kurang dari 1 (satu) tahun.

Hal ini sebenannya sudah sesuai dengan implementasi pasal 28D ayat (2) UUD 1945. Meskipun demikian, kenyataan dalam penerapanya penyebab tidak berjalanya peraturan di atas adalah Rumah Sakit itu sendiri. Rumah sakit tidak mengindahkan peraturan tersebut sehingga dalam hal ini dapat dikatakan bahwa Rumah Sakit tersebut telah melakukan perbuatan melawan hukum dengan memberikan upah lebih rendah dari UMK dan tidak menangguhkannya pekerjanya kepada Gubernur melalui Instansi yang bertanggung jawab di bidang ketenagakerjaan Provinsi.

Dari uraian tersebut di atas dapat disimpulkan bahwa secara legislasi Pemerintah telah melakukan pertanggungjawaban hukum kepada Tenaga Kesehatan sebagai pekerja di lingkup kesehatan Rumah Sakit, namun hal ini tidak dapat berjalan mulus sesuai rencana karena faktor Rumah Sakit itu sendiri.

\section{KESIMPULAN}

Berdasarkan hasil penelitian yang telah diuraikan di atas, dapat ditarik kesimpulan:

1. Bahwa pengupahan jasa tenaga kesehatan di bawah UMK dapat dilakukan penangguhan upah minimum, dan selisih upah yang ditangguhkan itu merupakan hutang Rumah Sakit yang tetap wajib dibayarkan. Apabila Rumah sakit tidak melakukan penangguhan upah minimum kepada tenaga kesehatan yang bekerja di Rumah Sakit, maka hal tersebut dikategorikan tindak kejahatan dengan 
sanksi pidana penjara paling singkat 1 (satu) tahun dan paling lama 4 (empat) tahun dan/atau denda paling sedikit Rp. 100.000.000,00 (seratus juta rupiah) dan paling banyak Rp. 400.000.000,00 (empat ratus juta rupiah).

2. Bahwa secara legislasi Pemerintah telah melakukan pertanggungjawaban hukum kepada Tenaga Kesehatan sebagai pekerja di lingkup kesehatan Rumah Sakit, namun hal ini tidak dapat berjalan mulus sesuai rencana karena faktor Rumah Sakit itu sendiri.

\section{SARAN}

Selanjutnya, sebagaimana kesimpulan yang telah peneliti uraikan tersebut di atas, adapun saran dalam penelitian ini di antaranya:

1. Pemerintah Daerah sebagai kepanjangan tangan dari Pemerintah Pusat perlu mengatur secara khusus peraturan tentang ketenagakerjaan di Fasilitas Pelayanan Kesehatan.

2. Dinas Ketenagakerjaan setempat perlu melakukan audit setiap tahunya di setiap Instansi Pelayanan Kesehatan meskipun tidak atau belum menerima laporan dari Instansi tersebut terkait penangguhan karyawanya.

3. Rumah Sakit perlu meninjau ulang Statuta Rumah Sakit terkait sistem penggajian karyawan, dan perlu mengacu kepada segala peraturan di bidang ketenagakerjaan daripada hasil pembuatanya nanti akan bertentangan dengan peraturan perundang-undangan yang berlaku.

4. Tenaga kesehatan sebagai seorang pekerja di lingkup kesehatan perlu keberanian untuk melaporkan jasa di bawah UMK yang dia terima kepada Dinas Ketenagakerjaan setempat.

\section{DAFTAR PUSTAKA}

\section{BUKU}

Aris Prio Agus Santoso, 2020, Hukum Kesehatan, Jakarta: Trans Info Media.

---------, 2020, Hukum Kesehatan (Pengantar Program Studi Sarjana Hukum), Yogyakarta: Pustaka Baru Press.

Aris Prio Agus Santoso, dan Erna Chotidjah Suhatmi, 2021, Hukum Ketenagakerjaan dan Penyelesaian

Perselisihan Hubungan Industrial, Yogyakarta: Nuta Media.

Burhan Ashsofah, 2010, Metode Penelitian Hukum, Jakarta: Rineka Cipta.

Daryanto, 1997, Kamus Bahasa Indonesia Lengkap, Surabaya: Apollo.

Herabudin, 2016, Studi Kebijakan Pemerintahan dari Filosofi ke Implementasi, Bandung: Pustaka Setia. Luthfi, Oman, Abdussalam, dan Masduki, 2015, Negara Kesejahteraan dan Pelayanan Sosial, Malang: Intrans Publishing.

Marbun, 2015, Peradilan Administrasi Negara dan Upaya Administratif Indonesia, Yogyakarta: FK UII Press.

Ridwan HR, 2014, Hukum Administrasi Negara, Jakarta: Rajawali Pers.

-------------, 2014, Diskresi dan Tanggungjawab Pemerintah, Yogyakarta: FH UII Press.

Sahya Anggara, 2018, Hukum Administrasi Negara, Bandung: Pustaka Setia.

Salim dan Erlies, 2013, Penerapan Teori Hukum pada Penelitian Tesis dan Disertasi, Jakarta: Rajawali

Pers

------------, 2017, Penerapan Teori Hukum, Jakarta: Rajawali Pers.

Soekidjo Notoatmojo, 2010, Etika dan Hukum Kesehatan, Jakarta: Rineka Cipta.

Sugiyono, 2010, Statistik Untuk Penelitian. Bandung: Alfabeta .

Universitas Katolik Soegijapranata, 2015, Petunjuk Penulisan Usulan Penelitian dan Tesis, Semarang:

Prodi Magister Ilmu Hukum Universitas Katolik Soegijapranata.

Titik Triwulan, dan Shinta Febran, 2010, Perlindungan Hukum bagi Pasien, Jakarta: Prestasi Pustaka.

Yohanes Budi Sarwo, 2012, Sistem Jaminan Sosial Kesehatan yang Berkeadilan dalam Negara Kesejahteraan di Indonesia, Semarang: Unversitas Katolik Soegijapranata.

Zainudin Ali, 2010, Metode Penelitian Hukum, Jakarta: Sinar Grafika. 


\section{JURNAL ILMIAH}

Amirus Sodiq, "Konsep Kesejahteraan dalam Islam”, dalam Jurnal Ekonomi Syariah, Vol. 3, No. 2, 2015.

Aris Prio Agus Santoso, dan Erna Chotidjah Suhatmi, "Pemutusan Hubungan Kerja Di Tengah Pandemi Covid-19 Ditinjau Dari Sudut Pandang Hukum Ketenagakerjaan”, UNIFIKASI: Jurnal Ilmu Hukum, Vol. 8, No. 1, 2021.

Aris Prio Agus Santoso, dan Tatina Siska Wardani, "Analisis Yuridis Kewenangan Perawat Dalam Pemberian Obat-Obatan Label Merah Pada Praktik Keperawatan Mandiri”, Yurisprudentia: Jurnal Hukum Ekonomi, Vol. 6, No. 1, 2020.

Aris Prio Agus Santoso, et.all, "Legal Protection of Health Workers in the Task Force for the Acceleration of Handling Covid-19 from a State Administrative Law Point of View", Jurnal Ilmu Sosial dan Ilmu Pendidikan, Vol. 5, No. 2, 2021.

Armansyah Waliam, "Upah Berkeadilan Ditinjau dari Perspektif Islam”, dalam Jurnal Bisnis, Vol. 3, No. 2, 2017.

Beriya Tangkari Utama, "Kebijakan Pemerintah dalam Pengaturan Komponen dan Tahapan, Pencapaian Hidup Layak Guna Mewujudkan Upah Layak", dalam Jurnal Hukum Universitas Lampung, Vol. 4, No.1, 2017.

Dian Ferricha, "Peninjauan Upah Hukum Positif Perspektif Doktrin Ekonomi Islam Mengenai Upah Syariah", dalam Jurnal An-Nisbah, Vo. 2, No. 1, 2015.

Devanto Shasta Pratomo, dan Putu Mahardika Adi Saputra, "Kebijakan Upah Minimum untuk Perekonomian yang Berkeadilan", dalam Journal of Indonesian Applied Economics, Vol. 5, No. 2, 2011.

Fenny Natalia Khoe, "Hak Pekerja yang Sudah Bekerja namun Belum Menandatangani Perjanjian Kerja atas Upah Ditinjau Berdasarkan Undang-Undang Nomor 13 tahun 2003 tentang Ketenagakerjaan”, dalam Jurnal Ilmiah Mahasiswa Universitas Surabaya, Vol. 2, No.1, 2013.

Jordan Kenjiro, Arda Tri Angga, dan Aris Prio Agus Santoso, "Hak Asasi Manusia Di Tinjau Dari Sudut Pandang Keadilan (Studi Kasus Munir)”, Prosiding HUBISINTEK, Vol. 1, 2020.

Mustari, "Hak atas Pekerjaan Upah yang Seombang”, dalam Jurnal Supremasi, Vol. 9, No. 2, 2016.

Rini Irianti Sundary, "Kebutuhan Meresepsi Kaidah-Kaidah Hukum Islam ke dalam Pengaturan Sistem Pengupahan bagi Para Pekerja di Indonesia", dalam Jurnal Ethos, Vol. 3, No. 1, 2005.

Rini Sulistiawati, "Pengaruh Upah Minimum terhadap Penyerapan Tenaga Kerja dan Kesejahteraan Masyarakat di Provinsi di Indonesia", dalam Jurnal EKSOS, Vol. 8, No. 3, 2012.

Sri Dewi Yusuf, "Konsep Penentuan Upah dalam Ekonomi Islam”, dalam Jurnal Al-Ulum, Vol. 10, No. $2,2010$.

Suyanto, dan Hendro Widiatmoko, "Legal Standing dalam Serikat Pekerja dalam Proses Penetapan Upah Minimum Sektoral Kabupaten/Kota”, dalam Jurnal Hukum Unigres, Vol. 20, No. 1, 2011.

Vivie Kartika Ayu, "Proses Perumusan Kebijakan Upah Minimum Kota Semarang Tahun 2016", dalam Jurnal Hukum Undip, Vol. 13, No. 2, 2016.

Zulkarnain Ibrahim, "Eksistensi Pengupahan yang Layak Berdasarkan Keadilan Substantif", dalam Jurnal Dinamika Hukum, Vol. 13, No. 3, 2013.

---------, "Hukum Pengupahan yang Berkeadilan Substantif (Kajian Teoritis Terhadap Teori Upah Teladan)", dalam Jurnal Dinamika Hukum, Vol. 42, No. 2, 2013.

\section{PERATURAN}

RI, Undang-Undang Dasar tahun 1945.

RI, Undang-Undang No. 39 tahun 1999 tentang Hak Asasi Manusia.

RI, Undang-Undang No. 40 tahun 2004 tentang Sistem Jaminan Sosial Nasional.

RI, Undang-Undang No. 11 tahun 2009 tentang Kesejahteraan Sosial. 
RI, Undang-Undang No. 36 tahun 2009 tentang Kesehatan.

RI, Undang-Undang No. 44 tahun 2009 Tentang Rumah Sakit.

RI, Undang-Undang No. 36 tahun 2014 tentang Tenaga Kesehatan.

RI, Peraturan Pemerintah No. 39 tahun 2012 tentang Penyelenggaraan Kesejahteraan Sosial.

RI, Peraturan Pemerintah No. 78 tahun 2015 tentang Pengupahan.

RI, Permenteri Tenaga Kerja dan Transmigrasi No. 7 tahun 2013 tentang Upah Minimum.

\section{INTERNET}

Elshinta.com, 2017, 424.000 Perawat di Indonesia Menganggur, diakses dari: https://www.elshinta.com/news/102610/2017/03/24/424-ribu-perawat-di-indonesia-menganggur (Tanggal 13 Mei 2019).

Portal Kesmas Indonesia, 2017, Pengangguran Tenaga Kesehatan di Sultra Capai 50.000 orang, diakses dari: http://kesmas-id.com/wow-pengangguran-tenaga-kesehatan-di-sultra-capai-50-000-orang/ (Tanggal 13 Mei 2019).

Risnakes, 2017, Laporan Riset Ketenagaan di Bidang Kesehatan (RISNAKES) 2017, diakses dari: http://labmandat.litbang.depkes.go.id/images/download/laporan/RIKHUS/2017/Laporan_RNK20 17_PKM.pdf (Tanggal 13 Mei 2019).

Warta Bromo, 2017, 20.000 Tenaga Perawat Baru di Jatim Menganggur Tak Diserap, diakses dari: https://www.wartabromo.com/2017/07/08/20-ribu-tenaga-perawat-baru-di-jatim-menganggurtak-terserap/ (Tanggal 13 Mei 2019). 